\title{
Generation of novel hyaluronic acid biomaterials for study of pain in third molar intervention: a review
}

\author{
Nadia Sultana Shuborna, Teeranut Chaiyasamut, Watus Sakdajeyont, Chakorn Vorakulpipat, Manus Rojvanakarn, \\ Natthamet Wongsirichat
}

Department of Oral \& Maxillofacial Surgery, Faculty of Dentistry, Mahidol University, Bangkok, Thailand

\begin{abstract}
Hyaluronic acid (HA) has long been studied in diverse applications. It is a naturally occurring linear polysaccharide in a family of unbranched glycosaminoglycans, which consists of repeating di-saccharide units of N-acetyl-Dglucosamine and D-glucuronic acid. It is almost ubiquitous in humans and other vertebrates, where it participates in many key processes, including cell signaling, tissue regeneration, wound healing, morphogenesis, matrix organization, and pathobiology. HA is biocompatible, biodegradable, muco-adhesive, hygroscopic, and viscoelastic. These unique physico-chemical properties have been exploited for several medicinal purposes, including recent uses in the adjuvant treatment for chronic inflammatory disease and to reduce pain and accelerate healing after third molar intervention. This review focuses on the post-operative effect of HA after third molar intervention along with its various physio-chemical, biochemical, and pharmaco-therapeutic uses.
\end{abstract}

Keywords: Biomaterial; Hyaluronic Acid; Third Molar; Intervention.

This is an Open Access article distributed under the terms of the Creative Commons Attribution Non-Commercial License (http://creativecommons.org/licenses/by-nc/4.0/) which permits unrestricted non-commercial use, distribution, and reproduction in any medium, provided the original work is properly cited.

\section{INTRODUCTION}

Hyaluronan or hyaluronic acid (HA) is a biomaterial that has proven valuable as an excellent alternative approach to accelerate wound healing [1]. HA is found in all living organisms in locations that include synovial fluid, embryonic mesenchyme, vitreous humor, skin and other many organ and tissues of the body [2]. HA interacts with growth factors and is involved in the regulation of osmotic pressure and tissue lubrication. It also interacts with many receptors that mediate cell detachment in mitosis, cell migration, tumor metastasis, and inflammation $[3,4]$. HA also participates in wound healing and prevents or reduces post-operative infla- mmation and the associated symptoms. The extracellular matrix (ECM) behaves like a gel, which allows tissues that are enriched in glycosaminoglycan to withstand strong mechanical pressure and accommodate a high rate of substance diffusion among cells [5]. Additionally, the non-immunogenic and non-toxic characteristics of HA allow its use in a variety of medical applications [1].

In 1997, a clinical trial explored the utility of HA's anti-inflammatory, anti-edematous, and anti-bacterial effects in the treatment of periodontal disease [6]. The ability of HA to lubricate and decrease articular wear, and its' metabolic properties that favor nutrition to avascular areas of the condylar cartilage and disk have been successfully used in traumatic, degenerative, and infl ammatory temporomandibular joints to improve function

Received: December 20, 2018 - Revised: January 20, 2019 - Accepted: January 30, 2019

Corresponding Author: Natthamet Wongsirichat, Oral Maxillofacial Surgery Department Faculty of Dentistry, Mahidol University 6 Yothi Street, Rachathewee District

Bangkok 10400, Consultant of Walailak University International College of Dentistry, Bangkok 10400, Thailand

Tel: +6602200777 ext 3333 Mobile phone: +66819095625 E-mail: natthamet.won@mahidol.ac.th

Copyright(c) 2019 Journal of Dental Anesthesia and Pain Medicine 
and reduce pain [7,8]. In periodontology, the hydrating property of HA is frequently used in aesthetic treatments $[9,10]$. HA has been employed in the treatment of gingivitis, recessions, and periodontal pockets, and as grafts and implants [9,10,11].

The third molar intervention is the most frequent procedure in oral surgery. The procedure can diminish the patients' quality of life in the first few days after the surgical intervention because of pain, swelling, and impeded capacity to open the mouth due to inflammation. As a consequence, daily life can be compromised. Postoperative sequelae include alveolar osteitis, nerve injury, bone fracture, and delayed healing [12]. Corticosteroids are popularly used to decrease the postoperative pain, edema, and limit inflammation following third molar intervention. However, potential side effects of perioperative corticosteroid usage include adrenal suppression, delayed wound healing, and increased susceptibility to infections [13,14].

HA biomaterial could be a better choice than corticosteroids for relief of the aforementioned post-operative sequelae after third molar intervention. This potential application is bolstered by the now-widespread use of HA in several other medicinal applications and the absence of contraindications, side effects, and interactions with drugs $[15,16]$. Indeed, HA is now the first choice in oral and maxillofacial interventions. Prior studies and reviews have addressed the role of HA in oral and maxillofacial surgery. This literature review considers the previous study regarding the effects of HA after third molar intervention with a focus on the physiochemical and biochemical properties of HA and an evaluation of postoperative sequalae.

\section{PREVIOUS STUDIES OF HYALURONAN/HA}

In 1934, Meyer and Palmer [17] reported that a hitherto unexplored chemical substance from the vitreous body of the eyes of cows contained two sugar molecules. One of the molecules was uronic acid. The authors also

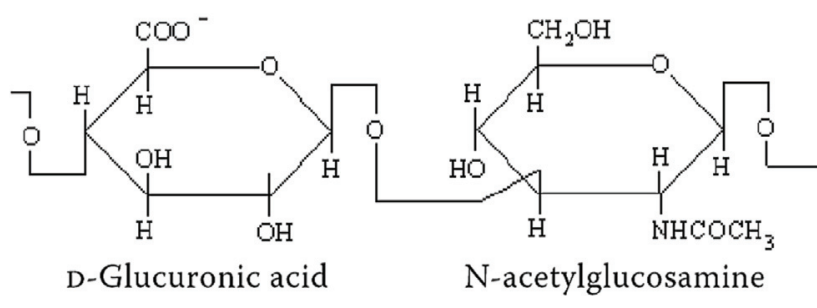

Fig. 1. Chemical structure of hyaluronic acid.

obtained the material from human umbilical cord, and shortly thereafter from rooster combs in a highly purified and high molecular weight form. The study essentially solved the chemical structure of hyaluronan. In 1950, the first study of the medical application of hyaluronan for humans was as a vitreous substitution during eye intervention. In 1986, Balazs et al. [18] distinguished hyaluronan from HA since, while HA is an acid, its physiological behavior was shown to be more like that of sodium hyaluronate salt.

\section{COMPOSITION OF HA}

HA is a di-saccharide comprising D-glucuronic acid and D-N-acetyl glucosamine linked together through alternating beta-1,4 and beta-1,3 glycosidic bonds (Fig. 1). The di-saccharide is very stable and strong. These properties are achieved via the constituent hydroxyl groups and the negative charge they impart. HA is very water-soluble $[19,20]$.

\section{BIOLOGICAL ACTIVITY OF HA}

HA functions biologically in the genesis, conservation, and resolution of inflammation [21]. It decreases prostaglandin actively responsible for inflammation and pain, and consequently improves collagen and promotes better healing and tissue repair [22]. With the presence of HA, de-polarization takes place in the inflammatory and pain processes, which alter tissue architecture and hinder metabolic exchange $[23,24]$. A recent report confirmed 
the roles of $\mathrm{HA}$ as an anti-inflammatory and ECM stabilizer by means of a protein complex that is an inter-alpha-inhibitor [25]. HA is a large and flexible molecule that can occupy a considerable volume with many free spaces [5], and is influential in regions where cell proliferation is pronounced. HA intervenes in the hydration-providing processes of growth and remodeling, and provides plastic properties to the mucosa. Enzymes that specifically degrade HA are hyaluronidases or hyaluro-glycosaminidases that are phylogenetically preserved from bacteria [26]. HA can act as a bridge for central proteins, like cartilage union protein, aggrecan, and versican, and is a backbone for large proteoglycan complexes. It regulates cell migration and proliferation by adhering with surface receptors, such as CD44, and is a hemagglutinin (HA) receptor expressed in leukocytes, epithelial cells, fibroblasts, and muscle cells. Physiologically, it preserves organic and tissue structure through cell-cell interactions and adhesion with the cell matrix. CD44 isoforms are involved in the initial bonding of leukocytes to endothelial cells activated by the infl ammation and pain processes. HA bonding with the CD44 receptor mediates the initial adhesion of inflammatory cells to the vessel, which allows extravasation rather than inflammation. Extracellularly, HA is synthesized by enzymes located on the cell surface without any covalent bonding to the protein core and HA synthetases (HAS) $[5,27]$.

\section{MECHANISM OF ACTIONS OF HA}

HA perform its biological actions according to two basic mechanisms. In the first, it can act as a passive structural molecule and a signaling molecule in size- and molecular weight-dependent manners. In the second mechanism, HA modulates tissue hydration, osmotic balance, and the physical properties of ECM, which is a hydrated and stable extracellular space to maintain cells, collagen, elastin fibers, and other ECM components [28].

The binding between $\mathrm{HA}$ and various proteins determines opposite actions, which include pro-infl ammatory and anti-inflammatory activities, promotion and inhibition of cell migration, and the activation and blockage of cell division and differentiation [29,30].

In the ECM, HA is present in the hyaluronate form. It is also found in the lung, kidney, brain, and muscle tissues, and in locations where friction occurs, which include joints, tendons, sheaths, pleura, and pericardium [31]. The mean life span of HA is approximately 2 to 3 days. The route of elimination is metabolism in the liver, local metabolism in the skin and joints, and via lymphatic pathways in other locales. In the blood, most of the HA (approximately $85-90 \%$ ) is eliminated in the liver, with approximately $10 \%$ extracted by the kidneys and the remaining 1 to $2 \%$ eliminated in the urine.

HA is a hygroscopic, viscoelastic, biocompatible, and non-immunogenic substance with anti-inflammatory, anti-edematous, and anti-oxidant properties [32]. In 2004, Jansen et al. [33] explored possible cytotoxic effects, biocompatibility, and degradation, and reported the lack of cytotoxicity and good biocompatibility. The structural homology of HA is maintained across species, as are the lack of antigenicity and immunogenicity, and the poor interaction with blood components. In 2003, Lim et al. [34] evaluated the neurotoxicity of epidural-administered HA in rabbits using light and electron microscopy. No rabbits showed any sensory-motor or behavioral changes during the three-week period, effectively ruling out neurotoxicity.

Various tumors, including epithelial, ovarian, colon, stomach, and acute leukemia tumors, overexpress the HA-binding receptors CD44 and RHAMM. These tumor cells are characterized by enhanced binding and internalization of HA. HA and HAS have been correlated with cancer progression. Excessive HAS activities increase the level of HA, which stimulates tumor growth and metastasis. But exogenous algometric HA inhibits tumor progression, which may occur by competing with endogenous polymeric HA. 
Table 1. Published articles of hyaluronic acid concerning clinical situation, age of sample, and evaluation of parameters

\begin{tabular}{|c|c|c|c|c|}
\hline Author & Year & Clinical situations & Sample size and mean age & Evaluated parameters \\
\hline $\begin{array}{l}\text { Koray } \\
\text { et al. [1] }\end{array}$ & 2014 & Sequelae of impacted third molar surgery & $\begin{array}{l}34 \text { patients, } \\
15 \text { males, } \\
19 \text { female } \\
\text { mean age } 23 \text { years }\end{array}$ & $\begin{array}{l}\text { Post-operative sequelae of pain, swelling, and } \\
\text { limited mouth opening. }\end{array}$ \\
\hline $\begin{array}{l}\text { Bayoum } \\
\text { et al. [36] }\end{array}$ & 2015 & $\begin{array}{l}\text { Dry socket and severity of post-extraction } \\
\text { pain after third molar surgery. }\end{array}$ & $\begin{array}{l}98 \text { patients } \\
40 \text { males, } \\
58 \text { females } \\
\text { mean age } 36 \text { years }\end{array}$ & Patients' pain levels by VAS \\
\hline $\begin{array}{l}\text { Gokhan G } \\
\text { et al. [40] }\end{array}$ & 2016 & Bleeding after third molar surgery. & $\begin{array}{l}40 \text { Patients } \\
\text { age range } 18-35 \text { years } \\
\text { mean age } 25 \text { years }\end{array}$ & $\begin{array}{l}\text { Maximum interincisal opening (MIO), } \\
\text { Pain scored on a visual analog scale (VAS), } \\
\text { Swelling }\end{array}$ \\
\hline $\begin{array}{l}\text { Yilmaz } \\
\text { et al. [39] }\end{array}$ & 2016 & $\begin{array}{l}\text { Pain, swelling, and trismus after third molar } \\
\text { surgery }\end{array}$ & $\begin{array}{l}\text { age range } 18-29 \text { years; median } \\
\text { age } 20 \text { years } \\
\text { mean age } 21 \text { years }\end{array}$ & $\begin{array}{l}\text { Postoperative pain, with VAS } \\
\text { Trismus, by inter incisal distance } \\
\text { Swelling by modified Gabka and Matsumara } \\
\text { method. }\end{array}$ \\
\hline $\begin{array}{l}\text { Dubovina } \\
\text { et al. [38] }\end{array}$ & 2016 & $\begin{array}{l}\text { Hyaluronic acid versus aminocaproic acid in } \\
\text { the treatment of alveolar ostitis }\end{array}$ & not assessed & not assessed \\
\hline $\begin{array}{l}\text { Bayoum } \\
\text { et al. [37] }\end{array}$ & 2018 & $\begin{array}{l}\text { Facial swelling, pain, and trismus after } \\
\text { surgical extraction of impacted mandibular } \\
\text { third molars. }\end{array}$ & $\begin{array}{l}14 \text { patients } \\
\text { seven males } \\
\text { seven females } \\
\text { age range } 25-40 \text { years mean age } \\
25 \text { years }\end{array}$ & $\begin{array}{l}\text { Maximum interincisal mouth opening } \\
\text { Pain by visual analogue scale } \\
\text { Swelling using three reference points }\end{array}$ \\
\hline $\begin{array}{l}\text { Afat } \\
\text { et al. [41] }\end{array}$ & 2018 & $\begin{array}{l}\text { Exploration of the clinical effect of leukocyte } \\
\text { and platelet-rich fibrin alone combined with } \\
\text { HA sponge }\end{array}$ & $\begin{array}{l}60 \text { patients } \\
\text { age range } 18-30 \text { years }\end{array}$ & $\begin{array}{l}\text { Edema measurement } \\
\text { Trismus measured by maximum inter incisal } \\
\text { opening, } \\
\text { Pain evaluated by visual analog scale }\end{array}$ \\
\hline
\end{tabular}

\section{HA MUTAGENICITY}

Reproductive toxicity multigenerational studies conducted using rats and rabbits who received intra-articular injections of hyaluronate sodium at doses of HA up to 11 times the anticipated human dose have revealed no evidence of impaired fertility or harm to fetuses [35].

HA has many important physiological and biological functions. Some important clinical applications include regulation of inflammation; enhanced cell migration, proliferation and differentiation; angiogenesis; osteoconduction; carrier function; bacteriostatic function; healing with less scarring; treatment of rheumatoid arthritis and knee osteoarthritis; and treatment of cataract and exophthalmia. In the latter ophthalmology applications, modifications of HA can provide some structure and rigidity to the gel that aids cell seeding.

HA can be used as a drug delivery material by various routes of administration. Tables 1 and 2 provide the results of a literature survey of English articles of randomized controlled clinical trials published from 2014 to 2018 describing the applications of HA in dentistry and oral and maxillofacial surgery [1,36-41].

\section{DISCUSSION}

HA is part of the main CD44 receptor that is involved in cell-cell interactions. Cytokine production is regulated by CD44 receptors and HA interactions [42]. Tumor necrosis factor inducible gene 6 protein influences pro-inflammatory cytokines by a negative feedback control mechanism and is an influential cross-linking agent of HA, which stimulates an inflammatory reaction that involves leukocyte infiltration, angiogenesis, and collagen.

Concerning the medical utility of HA, several previous studies reported that HA decrease symptoms, especially postoperative pain. Das et al. [43] reported that HA can 
Table 2. Summary of articles concerning use of hyaluronic acid $(\mathrm{HA})$ in the oral cavity

\begin{tabular}{|c|c|c|c|c|c|}
\hline \multirow[b]{2}{*}{ Author } & \multirow[b]{2}{*}{ Year } & \multicolumn{3}{|c|}{ Application } & \multirow[b]{2}{*}{ Results } \\
\hline & & HA GROUP & $\begin{array}{r}\text { CONTR } \\
\text { GROU }\end{array}$ & & \\
\hline $\begin{array}{l}\text { Koray } \\
\text { et al [1] }\end{array}$ & 2014 & $\begin{array}{l}0.2 \% \text { HA spray at third molar } \\
\text { socket }\end{array}$ & Benzydamine $\mathrm{H}$ & $\mathrm{ICl}$ spray & $\begin{array}{l}\text { - Patient postoperative swelling and trismus } \\
\text { - No statistically significant difference in pain scores }\end{array}$ \\
\hline $\begin{array}{l}\text { Bayoum } \\
\text { et al [36] }\end{array}$ & 2015 & $\begin{array}{l}0.3 \mathrm{ml} \mathrm{HA} \text { with gel foam at the } \\
\text { third molar socket. }\end{array}$ & Gel foam only & $\begin{array}{l}\text { No } \\
\text { application }\end{array}$ & $\begin{array}{l}\text { - No statistically significant differences in visual analog scale } \\
\text { scores between the three groups } \\
\text { - No statistically significant difference in dry socket } \\
\text { formation between the extraction sites of the three groups }\end{array}$ \\
\hline $\begin{array}{l}\text { Gokhan G } \\
\text { et al }[40]\end{array}$ & 2016 & $\begin{array}{l}\text { HA gel } 0.8 \%[\mathrm{w} / \mathrm{v}] \text { about } 0.2 \\
\mathrm{ml} \text { at the edge of the } \\
\text { extraction socket. }\end{array}$ & No application & & $\begin{array}{l}\text { - Prolonged bleeding time } \\
\text { - Increased hemorrhage } \\
\text { - Swelling in early postoperative period }\end{array}$ \\
\hline $\begin{array}{l}\text { Yilmaz } \\
\text { et al [39] }\end{array}$ & 2016 & $\begin{array}{l}0.8 \% \text { HA Gel at third molar } \\
\text { socket. }\end{array}$ & No application & & $\begin{array}{l}\text { - A good choice from clinical advantages for reducing usage } \\
\text { of non-steroidal anti-inflammatory drugs after third molar } \\
\text { surgery. }\end{array}$ \\
\hline $\begin{array}{l}\text { Dubovina } \\
\text { et al [38] }\end{array}$ & 2016 & $0.2 \mathrm{ml}$ of a $0.8 \%$ gel of $\mathrm{HA}$ & $\begin{array}{l}\text { Alveolo gel } \\
\text { plus HA }\end{array}$ & $\begin{array}{l}\text { Only } \\
\text { Alvelo gel }\end{array}$ & $\begin{array}{l}\text { - HA applied alone } \\
\text { - HA in combination with aminocaproic acid significantly } \\
\text { reduces pain sensation } \\
\text { - The number of symptoms and signs of alveolar ostitis } \\
\text { compared with the use of Alvogy }\left.\right|^{\circledR} \text { alone in the treatment } \\
\text { of alveolar ostitis. }\end{array}$ \\
\hline $\begin{array}{l}\text { Bayoum } \\
\text { et al [37] }\end{array}$ & 2018 & $\begin{array}{l}0.33 \mathrm{ml} \text { HA gel (HyaDENT } \\
\mathrm{BG}^{\circledR}, 20 \mathrm{mg} \mathrm{HA} / \mathrm{ml} \text { ) with } \\
\text { Gelfoam into third molar } \\
\text { socket. }\end{array}$ & Gel foam only & & $\begin{array}{l}\text { - Positive impact on postoperative swelling, pain, and } \\
\text { trismus after impacted third molar extraction, } \\
\text { - Reduced facial swelling, pain, and trismus. }\end{array}$ \\
\hline $\begin{array}{l}\text { Afat } \\
\text { et al [41] }\end{array}$ & 2018 & $\begin{array}{l}\text { Leukocyte and platelet-rich } \\
\text { fibrin (L-PRF) with HA sponge } \\
\text { in to third molar socket. }\end{array}$ & $\begin{array}{l}\text { L-PRF } \\
\text { alone }\end{array}$ & $\begin{array}{l}\text { No } \\
\text { application }\end{array}$ & $\begin{array}{l}\text { - Minimize postoperatively } \\
\text { - Edema after mandibular third molar surgery. Analgesic } \\
\text { intake on the day of surgery in the L-PRF + HA group } \\
\text { was significantly less than other groups. } \\
\text { - No significant difference among groups in trismus and } \\
\text { visual scale analoge pain score. }\end{array}$ \\
\hline
\end{tabular}

reduce symptoms of osteoarthritis knee pain as effectively as oral non-steroidal anti-inflammatory drugs or steroid injection. Gotoh et al. [44] reported an analgesic effect of HA that involves covering bradykinin receptors in synovial tissues. The data supported a role for HA as a pain medication. Nelson et al. [45] investigated the serum and the joint fluid in patients with knee osteoarthritis and described a remarkable decrease in the majority of inflammatory cytokines, including interleukin (IL) $-1 \alpha$, IL-1 $\beta$, IL-6, interferon, tumor necrosis factor-alpha, granulocyte macrophage colony stimulating factor, leptin, and bradykinin. The authors suggested that HA reduces pain as well as local and systemic inflammation. Longinotti [46] used HA matrix as a scaffold for platelet-rich plasma to treat open tendon wounds. HA was described as an ideal scaffold that promoted rapid remodeling and improved healing, thus facilitating early rehabilitation and return to function.

HA has an anti-inflammatory role that is manifest through the inhibition of tissue destruction. Longinotti et al. [46] also observed that the anti-edematous effects of HA might be associated with its' osmotic buffering capacity. The effects on edema agreed with previous findings. Leukocyte and platelet-rich fibrin applied along with HA produced a better result. Hanci and Altun [47] addressed the value of HA on pain relief following tonsillectomy. The main limitation of HA that was not cross-linked was its rapid washout within the first 12 hours following surgery. This rapid removal limited the applications of the material; however, a breakthrough seems possible since Abdalla et al. [48] reported increased new vessel formation and collagen deposition in an HA-based hydrogel group. The authors reported that leukocyte infiltration and angiogenesis that were 
consistent with the vessel and collagen findings, but that collagen deposition was not significantly different between the two study groups. Collagen deposition began at 3 to 4 days and reached its maximum level on day 14. The findings of the latter study indicate that the effects of collagen deposition should be examined after at least after 2 weeks. HA has a counter effect on reactive oxygen species. While Abdalla et al. [48] reported no significant difference concerning oxidative stress, other studies have providing convincing data that HA can scavenge free radicals and has anti-oxidant properties. The discrepancy may reflect the timing of the analysis after 1 week, which is too late for determination of oxidative stress and too early for examination of collagen deposition.

In oral and maxillofacial surgery of the third molar, HA alone was not as effective in the relief of inflammation as HA gel or spray using an HA sponge that bio-degrades slowly and releases biocompatible HA chains under a protective barrier, such as a P-LRF membrane, ensuring that an effective amount of HA remains in the socket during the first week of healing [46]. In this study the visual analog scale score did not differ significantly between the groups. Use of analgesic, patients' pain threshold, current mood and past experiences, lack of objective of pain assessment.

Prior studies on third molar surgery include Koray et al. [1], Gocmen et al. [49], Gokhan et al. [41], and Bayoum et al. [37]. The 2014 study of Koray et al. [1] evaluated the efficacy of HA compared to benzydamine hydrochloride to control pain, swelling, and limited mouth opening after third molar intervention. Postoperatively, limited mouth opening and edema were significantly reduced in the HA group compared to patients who received benzydamine hydrochloride. Gocmen et al. [49] assessed the anti-inflammatory and anti-oxidant effects of HA after third molar intervention. HA $(0.8 \%)$ displayed an anti-inflammatory effect. Following surgery, inflammation tends to peak within 1 to 2 days and usually resolves by the end of the first week. HA was beneficial to the process of healing after surgery to remove the impacted third molar. The reasons for the benefit included the formation of early granulation tissue and the inhibition of inflammation and postoperative pain. Gokhan et al. [40] explored the influence of HA on hemostasis after third molar intervention by measuring the tissue fluid level and bleeding time as primary outcomes, and visual analog scale score pain measurement, maximum inter-incisal opening, and swelling as secondary outcomes. The single application of HA in gel form could be a reason for the results. Moreover, hemostasis and hemorrhage to induce wound healing are complex mechanisms and involve numerous parameters.

In 2018, Bayoum et al. [37] studied the use of cross-linked HA following intervention for impacted mandibular third molar. The approach reduced postoperative swelling, pain, and limited mouth opening. Crosslinking of HA with polymer can prolong its retention for up to 7 days. This extended accessibility of HA at the wound site can reduce postoperative symptoms [50]. The uses of cross-linked HA have been recognized in various sites and situations in the oral cavity; as one example, HA gel can improve oral ulcers.

The many studies focusing on the oral cavity have included surgical extraction, dry socket formation, excisional biopsy of different oral tissues, and other oral surgeries. Often, no significant difference has been evident between study groups concerning pain scores. Surgical extraction typically requires some osteotomy and it can be assumed that all patients will experience some pain. Immediate pain relief would be beneficial. A 2015 study by Bayoumi et al. [36] reported the use of non-cross-linked HA did not decrease the incidence of dry socket formation and reduce postoperative pain. HA has been used for the healing of a variety of wounds and for pain relief without side effects. Bayoumi et al. [51] revealed that non-cross-linked HA had no effect on pain or dry socket following tooth extraction, although it likely dissolve in the first 12 hours. Also in 2016, Dubovina et al. [52] concluded that the use of HA with or without aminocaproic produced a statistically significantly faster reduction in pain along with the reduction in the number of symptoms and signs of alveolar osteitis or dry socket 
compared to the use Alvogyl ${ }^{\mathbb{R}}$. The data provided evidence of the benefit of HA on dry socket healing, although the mechanism of this phenomenon is still not clear. Yilmaz et al. [39] mentioned the postoperative satisfaction of oral surgery patients treated using an alternative anti-inflammatory and analgesic material with minimal adverse reactions. Local post-intervention administration of HA decreased pain. Romeo et al. [51] used a topical application of HA gel in combination with amino acids to enhance the healing by secondary intention for patients who had an excisional biopsy of different oral tissues. The authors reported that the sub-gingival application of cross-linked HA in patients with chronic periodontitis improved the gingival and bleeding indices. The study showed that HA gel accelerated the resolution of facial swelling, with relief realized at 7 days post-intervention.

When the dry socket is treated by HA placed into the wound, the material can act as a coagulum stabilizer to prevent unwanted excessive degradation. During wound healing, the fibrin threads form a web to produce a matrix for the platelet clot formation, followed by the production of HA. The HA molecules penetrate the fibrin matrix and stimulate cell migration, particularly fibroblasts from the surrounding tissue, and stimulate the production of new collagen. The additional HA probably stabilizes the coagulum and encourages wound healing.

In conclusion, HA is a biomaterial that is now widely used in many branches of medicine. It has compelling clinical potential as a consequence of the multi-functional attributes during wound healing. These attributes are being exploited in dentistry for the treatment of acute and chronic inflammatory diseases, and postoperative pain. The data from scientific and clinical studies have demonstrated the benefits of HA on tissue repair and wound healing. The administration of HA is valuable following oral and maxillofacial surgery with a significant improvement in the quality of life of patients. Further laboratory-based research and clinical trials are advisable to confirm these favorable and expected outcomes.
AUHOR ORGIIS

Nadia Sultana Shuborna: https://orcid.org/0000-0003-0245-4578 Teeranut Chaiyasamut: https://orcid.org/0000-0003-0487-5333

Watus Sakdajeyont: https://orcid.org/0000-0001-5921-989X

ChakornVorakulpipat: https://orcid.org/0000-0001-6627-8732

Manus Rojvanakarn: https://orcid.org/0000-0002-9986-8998

Natthamet Wongsirichat: https://orcid.org/0000-0003-3005-2680

ACKNOWLEDGMENT: The authors thank the staff and dental assistants, including colleagues and co-workers, in the Department of Oral and Maxillofacial Surgery, Faculty of Dentistry, Mahidol University.

FUNDING: None

CONFLICT OF INTEREST: The authors declare no conflict of interest.

ETHICS APPROVAL: Not required

\section{REFERENCES}

1. Koray M, Ofluoglu D, Onal EA, Ozgul M, Ersev H, Yaltirik M, et al. Efficacy of hyaluronic acid spray on swelling, pain, and trismus after surgical extraction of impacted mandibular third molars. Int J Oral Maxillofac Surg 2014; 43: 1399-403.

2. Orbak R, Ozturk M. Esthtetic applications at perioral region that fulfill intraoral treatments. J Dent Fac Atatürk Uni 2014; 24: 427-33.

3. Chen WY, Abatangelo G. Function of Hyaluronan in wound repair. Wound repair Regan 1999; 7: 79-89.

4. Teh BM. Shen Y, Friedland PL, Atlas MD, Marano RJ. A review on use of hyaluronic acid in tympanic membrane wound healing. Expert Opin Biol Ther 2012; 12: 23-36.

5. Junqueira LC, Carneiro J. Histologia Basica: Texto y Atlas. $12^{\mathrm{a}}$ Ed. Mexico, Editorial Panamericana; 2015: pp 3-101.

6. Pagnacco A, Vangelisti R, Erra C, Poma A. Double-blind clinical trial versus placebo of a new sodium-hyaluronatebased gingival gel. Attual Ter In 1997; 15: 1-7.

7. Laurent TC, Fraser JR. Hyaluronan. FASEB J 1992; 6: $2397-404$. 
8. Møystad A, Mork-Knutsen BB, Bjørnland T. Injection of sodium hyaluronate compared to a corticosteroid in the treatment of patients with temporomandibular joint osteoarthritis: a CT evaluation. Oral Surg Oral Med Oral Pathol Oral Radiol Endod 2008; 105: e53-e60.

9. Sato R, Yamamoto H, Kasai K, Yamauchi M. Distribution pattern of versican, link protein and hyaluronic acid in the rat periodontal ligament during experimental tooth movement. J Periodont Res 2002; 37: 15-22.

10. Violant D, Mor C, Santos A. Evaluación del efecto del gel de ácidohialurónico al 0.8\% comoadyuvanteen el tratamiento periodontal no quirúrgico. Estudiopiloto Dentum (Barc.) 2008; 8: 149-54.

11. Gontiya G, Galgali SR. Effect of hyaluronan on periodontitis: a clinical and histological study. J Indian Soc Periodontol 2012; 16: 184-92.

12. Blondeau F, Daniel NG. Extraction of impacted mandibular third molars: Postoperative complications and their risk factors. J Can Dent Assoc 2007; 73: 325.

13. McGrath C, Comfort MB, Lo EC, Luo Y. Changes in quality of life following after third molar surgery immediate post opeative period. $\mathrm{Br}$ dent J 2003; 195: 265-8.

14. Kim K, Brar P, Jakubowski J, Kaltman S. Lopez E. The use of corticosteroid and non steroidal anti-inflammatory medication for the management of pain and inflammation after third molar surgery: a review of literature. Oral Surg Oral Med Oral Pathol Oral Radiol Endod 2009; 107: 630-40.

15. Migliore A and Granata M. Intra-articular use of hyaluronic acid in the treatment of osteoarthritis. Clinical Interventions in Aging 2008; 3: 365-9.

16. Allegra L, Della Patrona S, Petrigni G. Hyaluronic acid: Perspectives in lung diseases. Handbook of Experimental Pharmacology 2012; 207: 385-401.

17. Meyer K, Palmer JW. The polysaccharide of the vitreous humor. J Biol Chem 1934; 07: 629-34.

18. Balazs EA, Laurent TC, Jeanloz RW. Nomenclature of hyaluronic acid. Biochem J 1986; 235: 903.

19. Cortivo R, De Galateo A, Haddad M, Caberlotto M, Abatangelo G. Glycosaminoglycans in human normal gingiva and in periodontosis: biochemical and histological observations. G Stomatol Ortognatodonzia 1986; 5: 69-72.

20. Necas J, Bartosikova L, Brauner P, Kolar J. Hyaluronic acid (hialuronan) a review. Vet Med 2008; 53: 397-411.

21. Badylak SF. Regenerative medicine and developmental biology: the role of the extracellular matrix. Anat Rec B New Anat 2005; 287: 36-41.

22. Engström PE, Shi XQ, Tronje G, Larsson A, Welander $\mathrm{U}$, Frithiof $\mathrm{L}$ et al. The effect of hyaluronan on bone and soft tissue and immune response in wound healing. J Periodontol 2001; 72: 1192-200.

23. Oksala O, Salo T, Tammi R, Häkkinen L, Jalkanen M, Inki $\mathrm{P}$, et al. Expression of proteoglycans and hyaluronan during wound healing. J Histochem Cytochem 1995; 43: 125-35.

24. Silvera-Arenas LA, Barrios de Zurbarán C. La matrizextracelular: el ecosistema de la célula. Salud Uninorte 2002; 16: 9-18.

25. Fries E, Kaczmarczyk A. Inter-alpha-inhibitor, hyaluronan and inflammation. Acta Biochim Pol 2003; 50: 735-42.

26. Necas J, Bartosikova L, Brauner P, Kolar J. Hyaluronic acid (hialuronan) a review. Vet Med 2008; 53: 397-411.

27. Alberts B, Bray D, Hopkin K, Johnson A, Lewis J, Raff M, et al. Introducción a la biologíacelular. 3a ed. Barcelona: Editorial Panamericana 2011: 571-80.

28. Dechert TA, Ducale AE, Ward SI, Yager DR. Hyaluronan in human acute and chronic dermal wounds. Wound Repair and Regeneration 2006; 14: 252-8.

29. Kosaki R., Watanabe K., Yamaguchi Y. Overproduction of hyaluronan by expression of the hyaluronan synthase Has2 enhances anchorage-independent growth and tumorigenicity. Cancer Res 1999; 59: 1141-5.

30. Camenisch TD, Spicer AP, Brehm-Gibson T, Biesterfeldt J, Augustine ML, Calabro A Jr, et al. Disruption of hyaluronan synthase- 2 abrogates normal cardiac morphogenesis and hyaluronan-mediated transformation of epithelium to mesenchyme. J Clin Investigation 2000; 106: 349-60.

31. Salwowska NM, Bebenek KA, Żądło DA, WcisłoDziadecka DL. Physiochemical properties and application of hyaluronic acid: a systematic review. J Cosmet Dermatol 2016; 15: 520-6.

32. Waddington RJ, Moseley R, Embery G. Reactive oxygen 
species: A potential role in the pathogenesis of periodontal diseases. Oral Dis 2000; 6: 138-51.

33. Jansen $K$, van der Werff JFA, van Wachem PB, Nicolai JP, de Leij LF, van Luyn MJ. A hyaluronan-based nerve guide: in vitro cytotoxicity, subcutaneous tissue reactions, and degradation in the rat. Biomaterials 2004; 25: 483-9.

34. Lim YJ, Sim WS, Kim YCh, Lee SCh, Choi YL. The neurotoxicity of epidural hyaluronic acid in rabbits: A light and electron microscopic examination. Anesthesia and Analgesia 2003; 97: 1716-20.

35. Product information. Orthovisc ${ }^{\circledR}$, Summary of safety and effectiveness data. 2004: 1-15.

36. Bayoumi AM, Jan A, Amoudi WA, Shakir M. The Effects of Using Hyaluronic Acid on the Extraction Sockets. Int J Dent Oral Health 2015; 2: doi http://dx.doi.org/ 10.16966/2378-7090.157.

37. Bayoum A, Nadershah M, Albandar A, Alsulaimani B, Sankour I, Gadi L, et al. The Effect of Cross-Linked Hyaluronic Acid in Surgical Extraction of Impacted Mandibular Third Molars. Int J Dent Oral Health 2018; 4: dx.doi.org/10.16966/2378-7090.254

38. Dubovina D, Mihailović B, Bukumirić Z, Vlahović Z, Miladinović M, Miković N, et al. The use of hyaluronic and aminocaproic acid in the treatment of alveolar osteitis. Vojnosanit Pregl 2016; 73: 1010-5.

39. Yilmaz N, Demirtas N, Kazancioglu HO, Bayer S, Acar $\mathrm{AH}$, Mihmanli A. The efficacy of hyaluronic acid in postextraction sockets of impacted third molars: A pilot study. Niger J Clin Pract 2017; 20: 1626-31.

40. Gocmen G, Aktop S, Tüzüner B, Goker B, Yarat A. Effects of hyaluronic acid on bleeding following third molar extraction. J Appl Oral Sci 2017; 25: 211-6.

41. Afat IM, Akdoğan ET, Gönül O. Effects of leukocyteand platelet-rich fibrin alone and combined with hyaluronic acid on pain, edema, and trismus after surgical extraction of impacted mandibular third molars. J Oral Maxillofac Surg 2018; 76: 926-32.

42. Wisniewski HG, Vilcek J. TSG-6: an IL-1/ TNF inducible protein with anti-inflammatory activity. Cytokines Growth Factor Rev 1997; 8: 143-56.

43. Das A, Neher JO, Safranek S. Clinical inquiries. Do hyaluronic acid injections relieve OA knee pain?J Fam Pract 2009; 58: 281c-e.

44. Gotoh S, Onaya J, Abe M. Effects of the molecular weight of hyaluronic acid and its action mechanisms on experimental joint pain in rats. Ann Rheum Dis 1993; 52: 817-22.

45. Nelson FR, Zvirbulis RA, Zonca B. The effects of an oral preparation containing hyaluronic acid (Oralvisc $(\mathrm{R})$ ) on obese knee osteoarthritis patients determined by pain, function, bradykinin, leptin, inflammatory cytokines, and heavy water analyses. Rheumatol Int 2015; 35: 43-52.

46. Longinott $C$. The use of hyaluronic acid based dressings to treat burns: A review. Burns Trauma 2014; 2: 162-8.

47. Hanc1 D, Altun H. Effectiveness of hyaluronic acid in post-tonsillectomy pain relief and wound healing: A prospective, double-blind, controlled clinical study. Int J Pediatr Otorhinolaryngol 2015; 79: 1388-92.

48. Abdalla S, Makhul G, Duong M, Chiu RC, Cecere R. Hyaluronan acid base hydrogel induces neovascularization and improves cardiac function in a rat model of myocardial infraction. Interact Cardiovasc Thorac surgery 2013; 17: 767-72.

49. Gocmen G, Gonul O, Oktay NS, Yarat A, Goker K. The anti oxidant and Anti anti-inflammatory efficiency of Hyaluronic acidafter 3rd molar extraction: J Craniomaxillofac Surg 2015; 43: 1033-7.

50. Williams DL, Mann BK. Efficacy of a crosslinked hyaluronic acid-based hydrogel as a tear film supplement: A masked controlled study. PLoS One 2014; 9: 1-6.

51. Romeo U, Libotte F, Palaia G, Galanakis A, Gaimari G, Tenore $G$, et al. Oral soft tissue wound healing after laser surgery with or without a pool of amino acids and sodium hyaluronate: a randomized clinical study. Photomed Laser Surg 2014; 32: 10-16. 